\title{
Does Partisanship Stop at Scandal's Edge? Partisan Resiliency and the Survival of Political Scandal
}

\author{
Jeronimo Cortina \\ University of Houston \\ Brandon Rottinghaus \\ University of Houston \\ bjrottinghaus@uh.edu
}

\begin{abstract}
The outbreak of political scandal depresses the approval ratings of the individuals involved, especially the president. Yet, less is known about the partisan effects of approval ratings during scandal, especially the "stickiness" of partisan ties to leaders involved in scandal. Using a survey experiment, we expose respondents to manufactured news coverage of both illegal and not illegal (mismanaged policy) activities involving President Obama. The results demonstrate that the President's co-partisans are more likely to approve of the President and less likely to desire to impeach the president, even after being informed about illegal activity. In contrast, out partisans are more likely to demand the President's impeachment for both illegal and not illegal activity. This article provides evidence of how partisanship persists (and even expands) during presidential scandals and how partisan linkages are important to surviving scandal.
\end{abstract}

Political scandals can have impacts that are minor and short-lived or major and long term, depending on the issues and players involved. The character of executives as revealed through scandal is consequential to American politics and can inform us about the governing style and public accountability of an elected executive. Pfiffner (2004) argues that "there is a widespread consensus in American politics that presidential character is just as important as intellect, organizational abilities, television presence, or effective public speaking" (6). Variations and violations of the implicit oath of reasonable harmony and clean governing are not tolerated by voters. Fousek and Wasserman (2010) argue that "the public has continued to demand ethical leadership from its elected representatives. This is particularly true of the president, who sits at the pinnacle of government and sets the moral tone for the executive branch" (2). Such character issues are associated with political responsiveness to the public, political judgments, fidelity to ones convictions and democratic legitimacy (Galston 2010). Scandals, and the events that precipitate or follow, have the potential to damage these often delicate relationships, especially in the aftermath of major violations.

Most presidents must deal with some form of political scandal while in office, either involving them directly, implicating them indirectly or those that involve their appointees, nominees or staff. Political cynicism may shape an individual's responses to these scandals (Dancey 2012). Certain types of scandal may affect public support differently than others and scandals that happened longer ago in time may have fewer consequences in declining approval than those that happened more recently (Doherty, Dowling and Miller 2011). Partisan politics plays a major role in the survival of scandal. Scholars have shown the key to surviving these affairs include public support and the ability to withstand an impeachment process as measured by the co-partisan base of legislative support (Rottinghaus 2014). Partisan politics clearly affects the politics of scandal as favorable partisans provide a soft cushion of support for a candidate 
embroiled in wrongdoing (Ginsberg and Shefter 1999; Shah, et al. 2002; Puglisi and Snyder 2011). The good news for presidents is that they can more easily maintain support of their fellow partisans (Edwards 2006) and, if necessary, persuade their fellow partisans to believe what the president says is correct (Ponder and Moon 2005) especially if the president's actions are viewed as more partisan (Kriner and Schwartz 2009).

We know that partisanship shapes voting behavior and impressions of politicians. Presidential public support is often based on core partisan support (Newman and Siegle 2010). We also know that partisan survival is stronger when a politician has more supporters (especially in the legislature). What we do not know is whether or not partisanship provides a political actor in a scandal with support through both legal and illegal activities. Do the president's partisans stick with him through all types of scandals? If the president is caught doing something illegal, will the president's partisans abandon him? In short, at what point and for which kinds of political scandal does partisan support become attenuated? In this article, using a survey experiment, we expose respondents to manufactured news coverage of both illegal and not illegal (mismanaged policy) activities involving President Obama. In effect, we want to understand how far partisan support can be stretched to protect a politician from loss of support or removal from office. In the following sections, we outline the effect of scandal on public opinion, describe how partisanship shapes attitudes towards the president, identify expectations of presidential partisan survival, outline the survey experiments to test the expectations and describe the conclusions. In doing so, this paper helps us to understand the dynamics of political scandal and the boundaries of political partisanship.

\section{Public Opinion and Political Scandals}

The easiest way to measure reputational damage due to scandals is to examine the decline in public support in public opinion polls. It is not a stretch to say that being associated with a scandal will harm the popularity of a politician, especially an executive. Newman and Forcehimes (2010) argue that negative events, such as scandals, have negative effects on presidential approval. They find that many scandals, including the breaking of the Iran-Contra scandal, the resignation of John Sununu and the exposure of the scandals at the Housing and Urban Development, in addition to other negative events, contribute negatively to presidential approval. An "approval diminishing" event, such as a scandal, combined with no rallying moment to galvanize the public, drops presidential approval by almost 3\% (Ostrom and Simon 1989). Although scandals tend to hurt the approval ratings of a politician, the public can distinguish between behavior it believes central to the actor's job and those it considers private (Renshon 2002). In fact, in isolated instances, presidents may actually maintain or even expand their popularity, depending on the specific conditions that are present (Zaller 1998). Prior approval of a politician and perceptions of the importance of the scandal also shape the attitudes of the public. In the case of President Clinton during the Lewinsky scandal, citizens "construct seemingly reasonable justifications" for what they believed and wanted to continue to believe: that the President was an effective leader (Fischle 2000, 151).

Why does scandal affect approval as it does? The degree of elite political cueing (either for or against a politician involved in scandal) has an effect on the evaluation of a hypothetical executive (Woessner 2005). A favorable (or unconcerned) media can frame the issues in a way 
that limits political damage. Favorable media attention also has an effect on public judgments. For instance, in the case of the Clinton-Lewinsky scandal, more media coverage in general is associated with a positive favorability of the President while more media coverage of the scandal is associated with a negative relationship on job approval (Kiousis 2003). More media coverage may also simply generate "white noise" that the public ignores (Lawrence, Bennett and Hunt 1999). Again, the type of scandal matters, where "competence qualities" are more important as an evaluative factor in a candidate evaluation (Funk 1996). Approval is also tied to how the scandal is framed. Shah, Watts, Domke and Fan (2002) note that the "mass approval of Clinton was sustained and encouraged by news content presenting the scandal in terms of attacks by conservatives and critical responses by liberals" in addition to partisan frames about the President's performance. Scandals also have the ability to prime the public's assessment of a politician's policy actions, as intervention in Central America "loomed larger" in the public's assessment of President Reagan's performance after the Iran-Contra scandal broke in November of 1986 (Krosnick and Kinder 1990).

\section{Presidential Partisans During Scandal}

We argue the president's partisans are key to their support and their political leadership. Essentially, presidents hope to remain in the good graces of their partisans during scandal in order to maintain a minimum level of public support to stay in office. Active partisan support provides ballast to a president as a means to allow sufficient public support. Party identity is among the stronger predictors of how voters evaluate party leaders or party platforms. Attachment to a partisan group is powerful and enduring, overwhelming several other possible predictors of behavior, and found to be as strong as religion or ethnic attachments (Green, Palmquist and Schickler 2002). The divergence in affective polarization between the parties, causing co-partisan judgements to be positive and out-partisan to be negative, has been increasing for decades (Baufumi and Shapiro 2009; Iyengar, Sood and Lelkes 2012). Political partisan attachments trump other judgements as well. Rosy judgements of fellow partisans are held in contrast to universally negative traits to those in the other party (Iyengar and Westdood 2015).

Partisanship is cemented by what political psychologists call "motivated reasoning" specifically citizens' opinions on policy are influenced by the party sponsoring the messages. Cues from members of a political party activate "heuristic processing" that assist partisans in understanding the party's message and minimizing the need for additional information (Petersen, et.al 2013). In other words, partisans are motivated to reach a conclusion that is consistent with the existing party's message. This cognitive heuristics are more likely to be employed by decision makers when the choice they face is complex.

Motivated reasoning shapes the way individuals "chunk" information and organize their knowledge, attitudes and inferences (Taber \& Lodge 2003) into "consistent, meaningful, discernible units and integrate that information with previously acquired information" (Markus et al. 1985, p.1496) in favor of correspondence biases (Nussbaum et al. 2003). When a respondent is confronted with arguments which are "attitudinally incongruent" they are still more likely to based their opinions on prior attitudes, demonstrating evidence of disconfirmation bias (Lau and Redlawsk 2001). There is also confirmation bias where people seek out confirmatory 
evidence leading to attitude polarization. Individuals with strong priors and high levels of political sophistication are more likely to engage in confirmation and disconfirmation bias (Taber \& Lodge 2006).

Although little work exists that documents partisan support during scandal, work in other elements of presidential leadership of or responsiveness to public opinion provides support to these assertions. Partisan politics can provide a ballast for presidents caught in the web of scandal in several ways. Empirical evidence suggests that partisan cues exert significant effects on political and non-political judgements (Iyengar and Westwood 2015). Indeed, partisans rally when presidents speak (Welch 2003; Edwards 2003; Tedin, et. al 2011), partisans are more attentive to the president's messages than others (Kernell and Rice 2011), especially recent presidents like President Obama (Milkis, Rhodes and Charnock 2012). Presidential approval is built on partisan approval (Ponder and Moon 2005; Newman and Siegle 2010) and the stability of partisan approval in enhanced with more partisan activity by the president (Kriner and Schwartz 2009).

Indeed, some scholarship identifies the role of partisanship in explaining political support during political scandals. Miller (2013) finds that exposure to scandalous information about a candidate had an immediate negative effect on evaluation, but the magnitude of this negative effect declined over time, especially among the candidate's supporters. Partisanship was a ballast against further slippage in the polls. Similarly, President Clinton was able to maintain his approval ratings (and his job as president) by persuading his supporters that he was still a credible and active political figure and the general public that the fervor surrounding the Lewinsky scandal was politically motivated (Sonner and Wilcox 1999). This may be because partisans are less likely to be attentive to the events of a presidential scandal (Dancey 2012). Partisan cues help in this phenomenon where presidential approval during scandal is strongly affected by elite partisan cues in addition to a priori public support from partisans (Woessner 2005).

Beyond public support, should an impeachment scenario arise, the president can leverage their partisan public support to maintain a minimum level of support and to forestall any possible removal from office. For instance, the president can use his skills to ensure co-partisan members of Congress vote with their party to support him (Edwards 2006; Beckmann 2010). Indeed, presidents have more success bargaining with members of their own party (Peterson 1990; Bond and Fleisher 1990). Edwards (2006) notes slippage in partisan support in Congress "forces the White House to adopt an activist orientation towards party leadership and sometimes devote as much effort to converting party members to support them as to mobilizing members of their party who already agree with them" (176, 272; see also Edwards 1989; Heith 2012, 133). Covington, Wrighton and Kinney (1995) argue that the president can influence legislative outcomes through the party leadership's influence on the rank-and-file members. Partisan support in the legislature has been demonstrated to link to survival of chief executives in office as a way to demonstrate the ability to govern and hold the line against impeachment (Rottinghaus 2014). Hinojosa and Perez-Linan (2006) note for presidents, where "popular presidents are more capable of enduring accusations, while declining presidential approval typically provides a strong signal for legislators to defect from the president's camp" (655). 


\section{From Inside the White House}

Internal White House discussions during scandal often point to support from the political base as a means to survive a scandal. All administrations can hope to control is their own party, and even this fete is difficult to pull off, even for a unified White House. In an internal White House document from William Timmons to General Alexander Haig where the impetus concerns where the President's partisans stand on their positions about impeachment of the President. Timmons notes that "only friends and possible 'swing' votes were contacted (no opponents)." Indeed, understanding and controlling the president's fellow partisans and keeping them in line may prove helpful in maintaining the president's survival. In a memoranda to Alexander Haig, at that point the acting Chief of Staff of the Nixon White House, only days before the President resigned, a staff member appealed to the Chief of Staff to take a public relations stand to “demonstrate the President's personal strength and resolve as President and also as leader of the Republican Party. This would increase the pressure on those Republicans thinking of jumping ship."1

The White House is also concerned about what partisan opponents think. For instance, in the aftermath of the scandal that led to the resignation of President Carter's Director of the Office of Management and Budget, Burt Lance, the President's pollster surveyed the effects of the scandal. Patrick Caddell, the President's pollster, wrote in a memorandum to the President "strongest approval of Lance's resignation came among Independents and Republicans; higherthan-average sentiment that Lance should remain in office was evidenced by those giving Carter an excellent performance record." Even after Senate Committee Hearings, headed by Senators Ribicoff and Percy, conducted an investigation, "a majority of both Republicans (53\%) and Carter detractors $(58 \%)$ approved of the way the Committee had conducted the hearing, with Independents (39\%), Carter supporters (40\%) and those that think Carter is doing an excellent job $(46 \%)$ were more likely to disapprove of the Senate Committee members' behavior."3 Ultimately, Caddell reported "while Democrats were slightly more inclined than either Independents or Republicans to view the President and Lance in a favorable light, differences were apt to be small, and an indication that the affair was not really a 'political issue."'4

\section{Expectations}

The previous sections outlined expectations that demonstrate that (1) presidents who maintain partisans support through scandal are more likely to survive the scandal and (2) presidents can maintain that support by engaging in partisan defenses of their actions. Given these past findings, in this section we identify specific expectations with respect to specific (but hypothetical) conditions a presidential administration may find themselves in during a scandal: a

\footnotetext{
${ }^{1}$ Richard Nixon Presidential Library, "House Impeachment Proceedings," Parker to Haig, David Gergen Papers, August 2, 1974, Staff Files, Box 111.

2 Jimmy Carter Presidential Library, “Aftermath of the Lance Resignation.” Caddell to the President, November 2 , 1977, Chief of Staff, “Caddell Patrick [1], Box 33.

${ }^{3}$ Ibid, page 10 .

${ }^{4}$ Ibid, page 14 .
} 
policy failure or illegal actions by the president. For a policy failure (but not illegal activity) the president's co-partisans should maintain their support of the president and remain less likely to support impeachment of the president. For an illegal policy activity, when the president is directly involved, the president's co-partisans should also maintain their support of the president and not support impeachment at similar rates as non-partisans. Given the severity of the charges (illegal activity) and consequences (impeachment) we expect presidential co-partisans to rally more to show firm support of their embattled party leader. In general, then, presidents should be able to count on support of their partisans during scandals and more so when the consequences are more severe.

On the other hand, out-partisans (those of the opposite party of the president) should decrease support of the president and be more likely to favor removal from office for the president in contrast to partisans for both of the scandal conditions presented (illegal and legal activity). Given their position as the opposition, being predisposed to oppose a president not of their party and receiving cues from their fellow opposition partisans (Shaw, Watts, Domke and Fan 2002), out-partisans should be more likely to be dissatisfied and disappointed with any presidential action that ends in failure or illegal activity. Although out-partisans can be persuaded to support a presidential policy initiative (Tedin, et al. 2011), the conditions that allow for opposition persuasion require a successful policy and direct persuasion from the president himself. Because the events in question in the experimental conditions here all describe failure, we should expect a negative effect on presidential approval and support for removal from office from out-partisans. However, because we are primarily interested in the president's partisans, we focus our analysis in the following sections on the president's partisans.

This theory yields three specific expectations. Because co-partisans are more likely to exhibit evidence of motivated reasoning (i.e., confirmation and disconfirmation bias) and reject arguments against their party's standard bearer we expect that partisans will be statistically significant less likely to support impeachment of the President when confronted with evidence of clear illegal wrong doing in comparison to out-partisans exposed to the same treatment (Expectation 1). We expect presidential support to be the same among Democrats whether they were exposed to the illegal policy frame or to the control frame (Expectation 2). We expect no statistically significant change for impeachment among presidential partisans when respondents were exposed to the policy mistake frame (Expectation 3).

\section{Experimental Survey Design}

In order to experimentally manipulate exposure to the two types of presidential speech formats, we conducted a survey experiment with undergraduate students at a major university in a large state in the southwest. In the spring semester of 2014, student subjects in nine Introduction to American Government classes ${ }^{5}$ were surveyed on a range of factual, policy, ideological and political issues. The surveys were done over the Internet using Qualtrics. A total of 1,013 subjects completed the survey. The sample was highly diverse, with a significant representation of African-Americans (13\%), Asians (28\%), Hispanics (any race 32\%) and Whites

\footnotetext{
${ }^{5}$ Introduction to American Government is a required. The students were given minor course credit for participating in the project.
} 
(38\%). We acknowledge the limitation of using a convenience sample of students who may not be representative as well as potential self-selection issues into a particular class. The only problem our sample would have is in the case that the size of the treatment effect would be dependent on certain characteristics (i.e., partisanship for the purpose of this paper) on which the sample has no variation (Drukman and Kam 2011), which is not the case for these data (see Table 2 below).

For the treatment manipulation portion of the experiment, the respondents were randomly assigned to one of three experimental treatment groups: one group was presented with a presidential "scandal" that involved illegal action, one group was presented with a presidential "scandal" that involved legal actions and one group was the control group who read a history of the Chicago Cubs. Random assignment to different treatment conditions ensures that the experimental units - in this case students - are probabilistically similar to each other on average, so any differences in the outcome variable potentially observed between groups are likely to be due to the treatment and not to confounding factors between the groups that existed at the beginning of the study (Fisher 1925, 1926; Shadish, Cook and Campbell 2002). After viewing their assigned speech, additional questions were asked to measure their approval of the president. The full text of the random treatments are shown in Table1. 
TABLE 1: Scandal Treatments

\begin{tabular}{|c|c|}
\hline "Illegal" Scandal Treatment & "Legal" Scandal Treatment \\
\hline $\begin{array}{l}\text { WASHINGTON -- Republican congressional } \\
\text { investigators have concluded that President Obama } \\
\text { is responsible for the failed Fast and Furious gun- } \\
\text { tracking operation that was "marred by illegal } \\
\text { actions, poor judgments and inherently reckless } \\
\text { strategy." } \\
\text { A federal operation dubbed Fast and Furious } \\
\text { allowed weapons from the U.S. to pass into the } \\
\text { hands of suspected gun smugglers so the arms } \\
\text { could be traced to the higher echelons of Mexican } \\
\text { drug cartels. The Bureau of Alcohol, Tobacco, } \\
\text { Firearms and Explosives, which ran the operation, } \\
\text { has lost track of hundreds of firearms, many of } \\
\text { which have been linked to crimes, including the } \\
\text { fatal shooting of Border Patrol Agent Brian Terry } \\
\text { in December } 2010 . \\
\text { According to a copy of the report obtained } \\
\text { Monday by Politico, the investigators said their } \\
\text { findings are "the best information available as of } \\
\text { now" about the flawed gun operation that last } \\
\text { month led to President Obama being found } \\
\text { subject to possible legal action against him. } \\
\text { The joint staff report, authored by Rep. Darrell } \\
\text { Issa (R-Vista), Chairman of the House Committee } \\
\text { on Oversight and Government Reform, and } \\
\text { Charles E. Grassley of Iowa, the top Republican } \\
\text { on the Senate Judiciary Committee, was highly } \\
\text { critical of the President. } \\
\text { They found that the President exhibited } \\
\text { "repeatedly risky" management and "consistently } \\
\text { pushed the envelope of legal investigative } \\
\text { techniques." Such action may be illegal and may } \\
\text { find the President himself in violation of several } \\
\text { domestic laws about firearm trafficking. }\end{array}$ & $\begin{array}{l}\text { WASHINGTON -- Republican congressional } \\
\text { investigators have concluded that President Obama } \\
\text { is directly responsible for the failed Fast and } \\
\text { Furious gun-tracking operation that was "marred } \\
\text { by missteps, poor judgments and inherently } \\
\text { reckless strategy." Investigators stopped short } \\
\text { of calling the operation illegal. } \\
\text { A federal operation dubbed Fast and Furious } \\
\text { allowed weapons from the U.S. to pass into the } \\
\text { hands of suspected gun smugglers so the arms } \\
\text { could be traced to the higher echelons of Mexican } \\
\text { drug cartels. The Bureau of Alcohol, Tobacco, } \\
\text { Firearms and Explosives, which ran the operation, } \\
\text { has lost track of hundreds of firearms, many of } \\
\text { which have been linked to crimes, including the } \\
\text { fatal shooting of Border Patrol Agent Brian Terry } \\
\text { in December } 2010 . \\
\text { According to a copy of the report obtained } \\
\text { Monday by Politico, the investigators said their } \\
\text { findings are "the best information available as of } \\
\text { now" about the flawed gun operation that last } \\
\text { month led to President Obama being charged } \\
\text { with failure to adequately oversee the } \\
\text { Department of Justice. } \\
\text { The joint staff report, authored by Rep. Darrell } \\
\text { Issa (R-Vista), Chairman of the House Committee } \\
\text { on Oversight and Government Reform, and } \\
\text { Charles E. Grassley of Iowa, the top Republican } \\
\text { on the Senate Judiciary Committee, was highly } \\
\text { critical of the Attorney General. } \\
\text { They found that the President exhibited } \\
\text { "repeatedly risky" management and "consistently } \\
\text { pushed the envelope of legal investigative } \\
\text { techniques without breaking any laws." Such } \\
\text { action did not violate any laws but has exposed } \\
\text { weaknesses in the Administration's policies to } \\
\text { control gun trafficking. }\end{array}$ \\
\hline
\end{tabular}

NOTE: Bold type specifies alteration of language in the "Politico" news story.

The sample provides a convenient way to test the theoretical expectations outlined in this paper. Student samples pose a problem when in the case of an heterogeneous treatment effect one that is moderated by individual-level characteristics- is contingent upon a trait (i.e., partisanship for the purpose of this paper) on which the sample has no variance (Druckman and Kam 2011). However, as Druckman and Kam (2011) show if the heterogeneous treatment effect is theorized in terms of how it should vary along a specific covariate then it is possible to estimate the treatment effect as long as there is sufficient variation in the sample. In this case the treatment effect will be accurately estimated and with significant confidence (Druckman and 
Kam 2011). Table 2 shows the frequency distribution of the outcome, treatment assignment, predictor and control variables.

TABLE 2: Frequency Distribution

\begin{tabular}{|c|c|c|c|c|}
\hline & All & $\begin{array}{l}\text { Illegal } \\
\text { Policy }\end{array}$ & $\begin{array}{l}\text { Legal } \\
\text { Policy }\end{array}$ & Contro \\
\hline Impeach & $20 \%$ & $23 \%$ & $18 \%$ & $20 \%$ \\
\hline \multicolumn{5}{|l|}{ Treatment Assignment } \\
\hline Illegal Policy & $33 \%$ & -- & -- & -- \\
\hline Legal Policy & $33 \%$ & -- & -- & -- \\
\hline Control & $34 \%$ & -- & -- & -- \\
\hline \multicolumn{5}{|l|}{ Party ID } \\
\hline Democrat & $35 \%$ & $37 \%$ & $34 \%$ & $34 \%$ \\
\hline Independent & $40 \%$ & $38 \%$ & $43 \%$ & $39 \%$ \\
\hline Republican & $23 \%$ & $22 \%$ & $22 \%$ & $25 \%$ \\
\hline Other & $2 \%$ & $3 \%$ & $2 \%$ & $2 \%$ \\
\hline \multicolumn{5}{|l|}{ Ideology } \\
\hline Very liberal & $5 \%$ & $7 \%$ & $6 \%$ & $3 \%$ \\
\hline Liberal & $26 \%$ & $25 \%$ & $26 \%$ & $28 \%$ \\
\hline Moderate & $49 \%$ & $49 \%$ & $49 \%$ & $50 \%$ \\
\hline Conservative & $16 \%$ & $16 \%$ & $16 \%$ & $16 \%$ \\
\hline Very Conservative & $3 \%$ & $3 \%$ & $4 \%$ & $3 \%$ \\
\hline \multicolumn{5}{|l|}{ Presidential Approval } \\
\hline Unfavorable & $12 \%$ & $11 \%$ & $11 \%$ & $14 \%$ \\
\hline Somewhat unfavorable & $14 \%$ & $14 \%$ & $14 \%$ & $14 \%$ \\
\hline Neutral & $38 \%$ & $40 \%$ & $36 \%$ & $37 \%$ \\
\hline Somewhat favorable & $25 \%$ & $25 \%$ & $24 \%$ & $25 \%$ \\
\hline Favorable & $11 \%$ & $10 \%$ & $14 \%$ & $10 \%$ \\
\hline \multicolumn{5}{|l|}{ Race \& Ethnicity } \\
\hline Hispanic & $32 \%$ & $32 \%$ & $33 \%$ & $31 \%$ \\
\hline Asian & $28 \%$ & $28 \%$ & $32 \%$ & $26 \%$ \\
\hline Black & $13 \%$ & $12 \%$ & $12 \%$ & $15 \%$ \\
\hline White & $38 \%$ & $41 \%$ & $33 \%$ & $39 \%$ \\
\hline Sex & $54 \%$ & & & \\
\hline Female (\%) & & $54 \%$ & $52 \%$ & $56 \%$ \\
\hline
\end{tabular}


In terms of partisan affiliation, for instance, our data reflects the national distribution among "Millennials" (born 1981-1994). A poll by the Pew Research Center (2012) reports that among millenials, $45 \%$ self-identify as independents, $31 \%$ as Democrats and $18 \%$ as Republicans. Ideologically, almost half of the respondents (49\%) self-identified as ideologically moderates, while only 5\% and 3\% self-identified as very liberal and very conservative, respectively. Given the overrepresentation of Hispanics, African Americans and Asians as identified above, our sample provides a unique opportunity to test for any potential ethnoracial effects that could mediate the relationship between partisanship and political scandals. Below in Figure 1 we assess the mean values across groups and find that there are no significant imbalances across groups.

The scandal in question was adapted from the misbegotten "fast and furious" gun trading scandal during the Obama Administration in 2011 and 2012. The Los Angeles Times summarizes federal operation "Fast and Furious" as where The Bureau of Alcohol, Tobacco, Firearms and Explosives "allowed weapons from the U.S. to pass into the hands of suspected gun smugglers so the arms could be traced to the higher echelons of Mexican drug cartels. The Bureau of Alcohol, Tobacco, Firearms and Explosives, which ran the operation, has lost track of hundreds of firearms, many of which have been linked to crimes, including the fatal shooting of Border Patrol Agent Brian Terry in December 2010." Congressional Republicans Representative Darrell Issa of California (Chair of the House Oversight Committee) and Senator Charles Grassley of Iowa (Ranking Member on the Senate Judiciary Committee) investigated the scandal to determine the scope of the failed policy and held a series of hearings in 2011 and 2012. Attorney General Eric Holder was called to testify in front of the Senate Judiciary Committee where he decried the "gotcha" politics (Hennessey 2011). The White House evoked executive privilege to restrict access to certain internal deliberations (Jackson 2012). As a result, the House of Representatives, along partisan lines, held the Attorney General in contempt of Congress for failing to disclose those documents the Committee desired (Weisman and Savage 2012).

Although the operation lead to deadly ramifications, twenty individuals were indicted in 2011 on charges of buying high-powered firearms in Arizona to be used by Mexican drug gangs and were sentenced in federal court to 57 months in prison in 2012 (Perry 2012).

There are several advantages to experimentally using the "fast and furious" scandal, the first major scandal of the Obama Administration. First, the event meets the classic definition of a scandal. For instance, Marion (2010) requires that a public figure has been "accused of unethical or immoral behavior" defined as offending behavior or an event "that is disgraceful, shameful or discredits someone" or that transgresses "societal norms, moral codes or values" (11). Thompson (2000) offers a detailed definition which requires that actions "transgress or contravene certain values, norms or moral codes" and that the actions' disclosure might damage responsible individuals' reputations, so that they attempt to conceal the action. For the White House, "by attempting to limit its exposure to the fallout, the Obama administration only helped Republicans build their case that a nefarious coverup occurred" (Barrett 2013). Second, we can experimentally manipulate whether or not the actions undertaken were legal or illegal. This distinction is imperative because it gets at the core of the research question concerning when and

\footnotetext{
${ }^{6} \mathrm{http}: / /$ www.latimes.com/news/nationworld/nation/atf-fast-furious-sg,0,3828090.storygallery\#ixzz2swxd6BCF
} 
whether or not the president's partisans stick with or abandon him during scandals which are alternatively legal or illegal. Third, the events from "fast and furious" were both domestic and international, spanning the president's presumed policy advantages on issues of foreign policy and national security.

\section{Findings: Does Partisanship Restrict Scandal?}

Figure 1 presents the mean values and 95\% confidence intervals for our outcome variable as well as for our main confounding variables. Given the experimental design we expect that the differences between treatment groups are not statistically significant. The patterns depicted in Figure 1 confirm that respondents assigned to each treatment condition are, on average probabilistically similar to each other, we would expect then that any observed differences in the outcome variable observed between groups are likely to be due to treatment and not to pretreatment confounding factors. We begin with a $t$-test to compare the mean values of our outcome variable (i.e., impeachment) between those who were assigned to the policy illegal condition and self-identified as Democrats versus those who self-identified as Republicans, Independents or something else and were randomly assigned to the policy illegal condition. The mean value for the former group is $11 \%$, while for the latter is $30 \%$. Partisans were statistically significant $(p<0.01)$ less likely to say that they wanted the President to be impeached than nonpartisans suggesting that even after being informed about the illegal activity partisans kept rallying behind the President (see Table A1 in the Appendix).

\section{FIGURE 1. Balance in Averages of Treatment and Covariates across Treatment Groups with $95 \%$ Confidence Intervals}

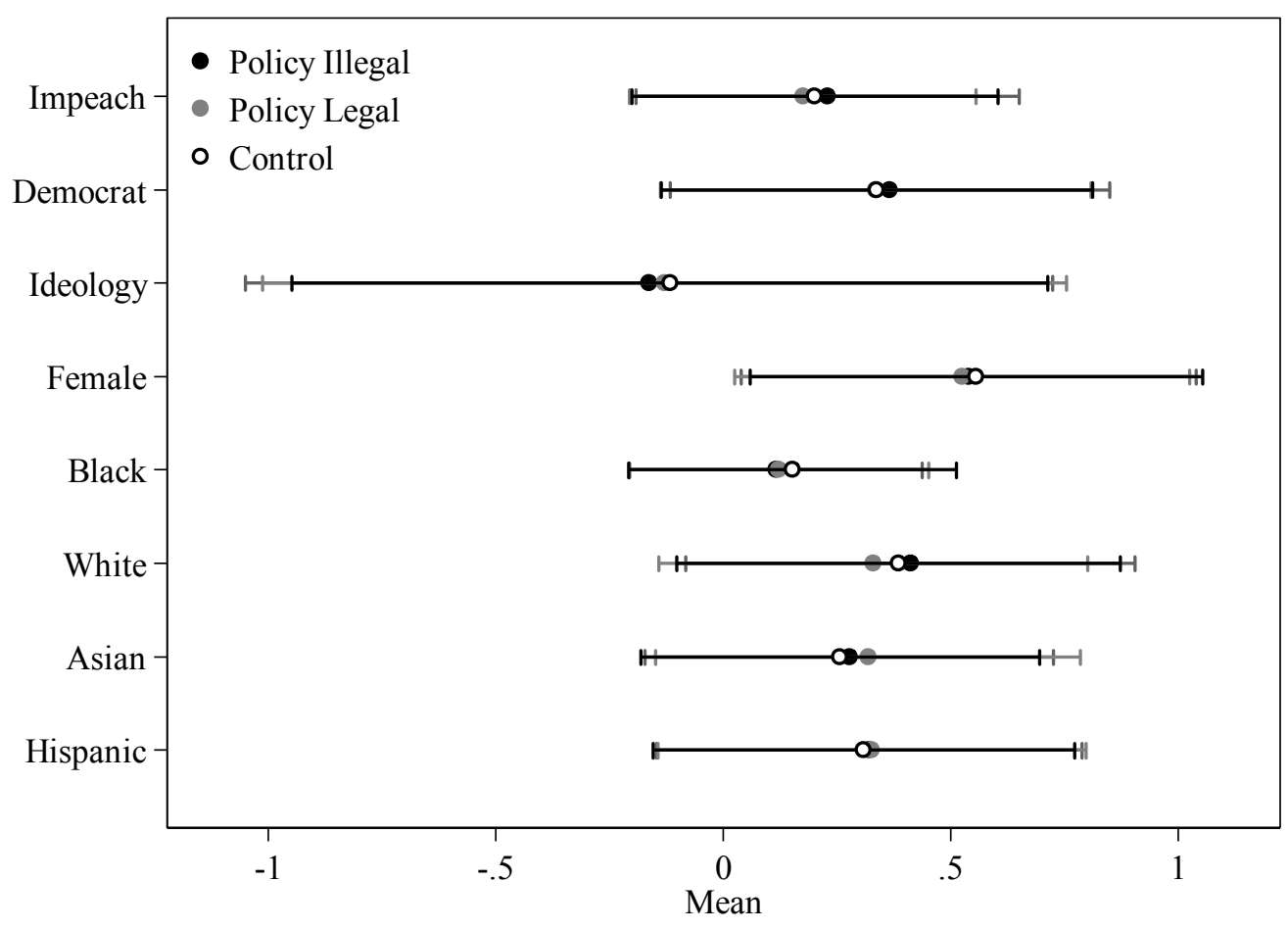


To further test the relationship between partisanship and scandals we fit a series of logistic regression models estimating the probability of impeachment conditional on treatment assignment (whether respondents were randomly assigned to either the presidential scandal that involved an illegal action or to the presidential scandal that involved legal actions) in comparison to those who were randomly assigned to the control group (those who read a history of the Chicago Cubs). Given that we are interested in knowing if partisans tend to stick with the President under a scandal we interact partisanship and treatment assignment. In addition, we control for ideology (very liberal to very conservative), sex (female $=1)$, race (White, Black/ African-American, Asian) and ethnicity (Hispanic =1). Furthermore, to test if partisans "stick" with the president, that is, whether partisans have an unfavorable, somewhat unfavorable, neutral, somewhat favorable or favorable opinion on the president we fit two ordered-logit regression models predicting presidential approval sub-setting the data by treatment, that is, by whether respondents were assigned to the scandal involving. Overall, we expect that partisans will be both less likely to want to see the president impeached and more likely to have a favorable opinion on the president in both scandal treatments.

The President illegal frame is the toughest test of the theory because it presents a clear impeachable offense so we specifically focus on that treatment here. The first model estimates the probability of impeachment when respondents are exposed to the presidential "scandal" that involved an illegal action in comparison to respondents who were exposed to the control condition. The results are summarized in Table 3, which presents the estimates of a logit model providing support for Expectation 1. The results show that those who were exposed to the illegal presidential political scandal were more likely to indicate that the President should be impeached $(\mathrm{p}<0.05)$, while partisans were less likely to indicate that the President should be impeached but its impact is not statistically significant at traditional levels. The interaction between Democrat and being exposed to the political scandal indicates that Democrats exposed to the treatment condition were less likely in a statistically significant way $(\mathrm{p}<0.05)$ to indicate that the President should be impeached. In terms of our confounding variables, ideology works in the expected theoretical direction in the sense that more conservative individuals are more likely to indicate that the President should be impeached but its impact is not statistically significant at traditional levels $(\mathrm{p}<0.10)$. Being a female, Black, White, Asian or Hispanic, per se, does not have a significant impact on the probability of indicating that the President should be impeached. 
TABLE 3: Logit Regression predicting the probability of impeachment for respondents exposed to a political scandal that involved an illegal action

\begin{tabular}{|c|c|}
\hline & Coef. \\
\hline \multirow[t]{2}{*}{ Policy Illegal } & $0.44 * *$ \\
\hline & $(0.22)$ \\
\hline \multirow[t]{2}{*}{ Democrat } & -0.01 \\
\hline & $(0.32)$ \\
\hline \multirow[t]{2}{*}{ Policy Illegal x Democrat } & $-1.16 * *$ \\
\hline & $(0.45)$ \\
\hline \multirow[t]{2}{*}{ Ideology } & $0.23 *$ \\
\hline & $(0.12)$ \\
\hline \multirow[t]{2}{*}{ Female } & 0.23 \\
\hline & $(0.20)$ \\
\hline \multirow[t]{2}{*}{ Black } & -0.27 \\
\hline & $(0.40)$ \\
\hline \multirow[t]{2}{*}{ White } & 0.01 \\
\hline & $(0.27)$ \\
\hline \multirow[t]{2}{*}{ Asian } & -0.02 \\
\hline & $(0.32)$ \\
\hline \multirow[t]{2}{*}{ Hispanic } & -0.05 \\
\hline & $(0.24)$ \\
\hline \multirow[t]{2}{*}{ Constant } & $-1.41 * * *$ \\
\hline & $(0.32)$ \\
\hline Observations & 657 \\
\hline PseudoR $^{2}$ & 0.0373 \\
\hline$\chi^{2}$ & 25.62 \\
\hline $\mathrm{p}>\chi^{2}$ & 0.00236 \\
\hline
\end{tabular}


Figure 2 plots the predictive margins with $95 \%$ confidence intervals illustrating the treatment effect of being exposed to the presidential scandal and partisanship. Democrats (black circle) exposed to the treatment condition were $18 \%$ less likely than out-partisans (gray circle) to indicate that the President should be impeached. Democrats and non-Democrats exposed to the control condition were $20 \%$ and $21 \%$ more likely to indicate that the President should be impeached, respectively (see Table A2 in the Appendix for predictive margins).

\section{FIGURE 2. Control Group Versus President Illegal Activity Comparison}

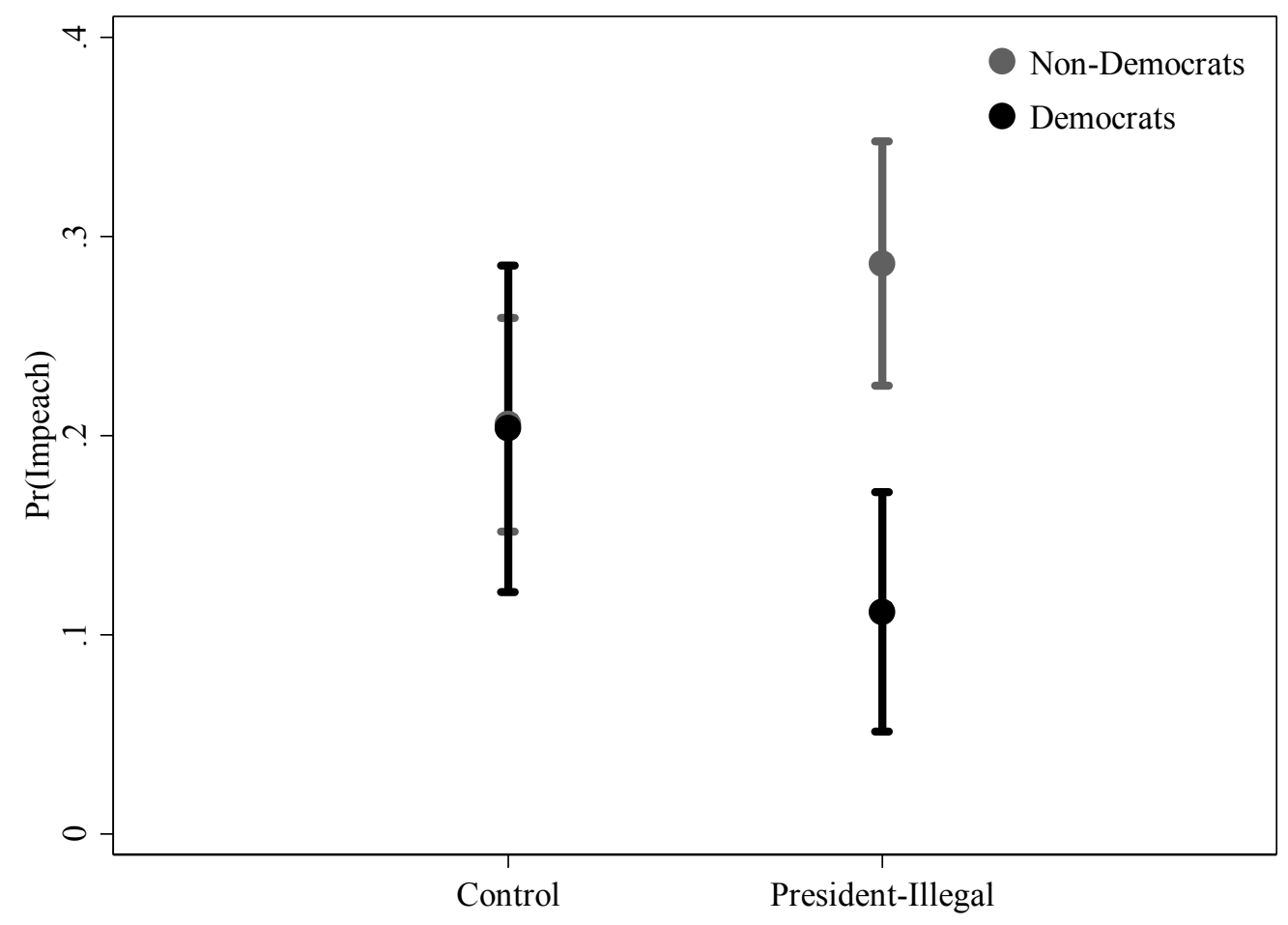

Knowing that partisans are less likely to indicate that the President should be impeached given his illegal involvement only takes us half way. In order to test if partisanship restricts scandals we need to estimate the likelihood of "sticking" with the President during bad times. Using an ordered-logit regression, our second tests predict presidential approval conditional on whether respondents were exposed to the presidential "scandal" that involved an illegal action or the control. Table 4 summarizes the results of two models which include party and all the relevant controls that might impact presidential approval. The findings lend support of Expectation 2. The aim of these models is to test whether co-partisanship will hold regardless of treatment assignment, that is, regardless of whether respondents were exposed to the illegal presidential scandal frame or to the control frame. 
TABLE 4: Ordered logit regression predicting Presidential support

\begin{tabular}{|c|c|c|}
\hline & $\begin{array}{l}\text { Policy } \\
\text { Illegal } \\
\text { Coef. }\end{array}$ & $\begin{array}{c}\text { Control } \\
\text { Condition } \\
\text { Coef. }\end{array}$ \\
\hline \multirow[t]{2}{*}{ Democrat } & $1.29 * * *$ & $1.42 * * *$ \\
\hline & $(0.25)$ & $(0.27)$ \\
\hline \multirow[t]{2}{*}{ Ideology } & $-0.71 * * *$ & $-0.70 * * *$ \\
\hline & $(0.13)$ & $(0.14)$ \\
\hline \multirow[t]{2}{*}{ Female } & -0.13 & 0.18 \\
\hline & $(0.21)$ & $(0.21)$ \\
\hline \multirow[t]{2}{*}{ Black } & $1.48^{* * *}$ & $1.14 * * *$ \\
\hline & $(0.42)$ & $(0.40)$ \\
\hline \multirow[t]{2}{*}{ White } & -0.43 & -0.37 \\
\hline & $(0.30)$ & $(0.30)$ \\
\hline \multirow[t]{2}{*}{ Asian } & 0.57 & 0.56 \\
\hline & $(0.35)$ & $(0.35)$ \\
\hline \multirow[t]{2}{*}{ Hispanic } & $0.60 * *$ & 0.25 \\
\hline & $(0.27)$ & $(0.26)$ \\
\hline \multirow[t]{2}{*}{ Cut 1} & $-1.92 * * *$ & $-1.44 * * *$ \\
\hline & $(0.36)$ & $(0.36)$ \\
\hline \multirow[t]{2}{*}{ Cut 2} & $-0.66^{* *}$ & -0.38 \\
\hline & $(0.34)$ & $(0.34)$ \\
\hline \multirow[t]{2}{*}{ Cut 3} & $1.64 * * *$ & $1.74 * * *$ \\
\hline & $(0.35)$ & $(0.36)$ \\
\hline \multirow[t]{2}{*}{ Cut 4} & $3.66^{* * *}$ & $3.73 * * *$ \\
\hline & $(0.40)$ & $(0.41)$ \\
\hline Observations & 331 & 325 \\
\hline PseudoR ${ }^{2}$ & 0.136 & 0.132 \\
\hline$\chi^{2}$ & 131.0 & 127.7 \\
\hline $\mathrm{p}>\chi^{2}$ & 0 & 0 \\
\hline
\end{tabular}

In general, co-partisan Democrats were more likely to have a favorable opinion of President Obama $(\mathrm{p}<0.01)$. Democrats who were assigned to the treatment condition were $15 \%$ more likely to have a favorable opinion of President Obama, while non-Democrats were only 5\% more likely to have a favorable opinion on the President after exposed to the illegal frame (see Table A3 in the Appendix). Five percent appears high especially following a treatment where they were told that the president has done something illegal but the non-democrat category includes both Republicans and Independents who may lean Democratic. In contrast, Democrats 
exposed to the presidential illegal scandal were 3-times less likely to hold an unfavorable opinion on the President (4\%) in comparison to non-Democrats (12\%) (see Table A3 in the Appendix). Figure 3 shows the predicted probabilities for Democrats (black line) and nonDemocrats (gray line) in the treatment condition. Figure 3's pattern shows that Democrats who were randomly assigned to presidential scandal that involved an "illegal" action tend to "stick" with the President during a scandal (see Tables A3 and A4 for predicted probabilities).

\section{FIGURE 3: Predicted probabilities for presidential approval for Democrats and Non- Democrats in the Scandal "Illegal" Treatment Condition}

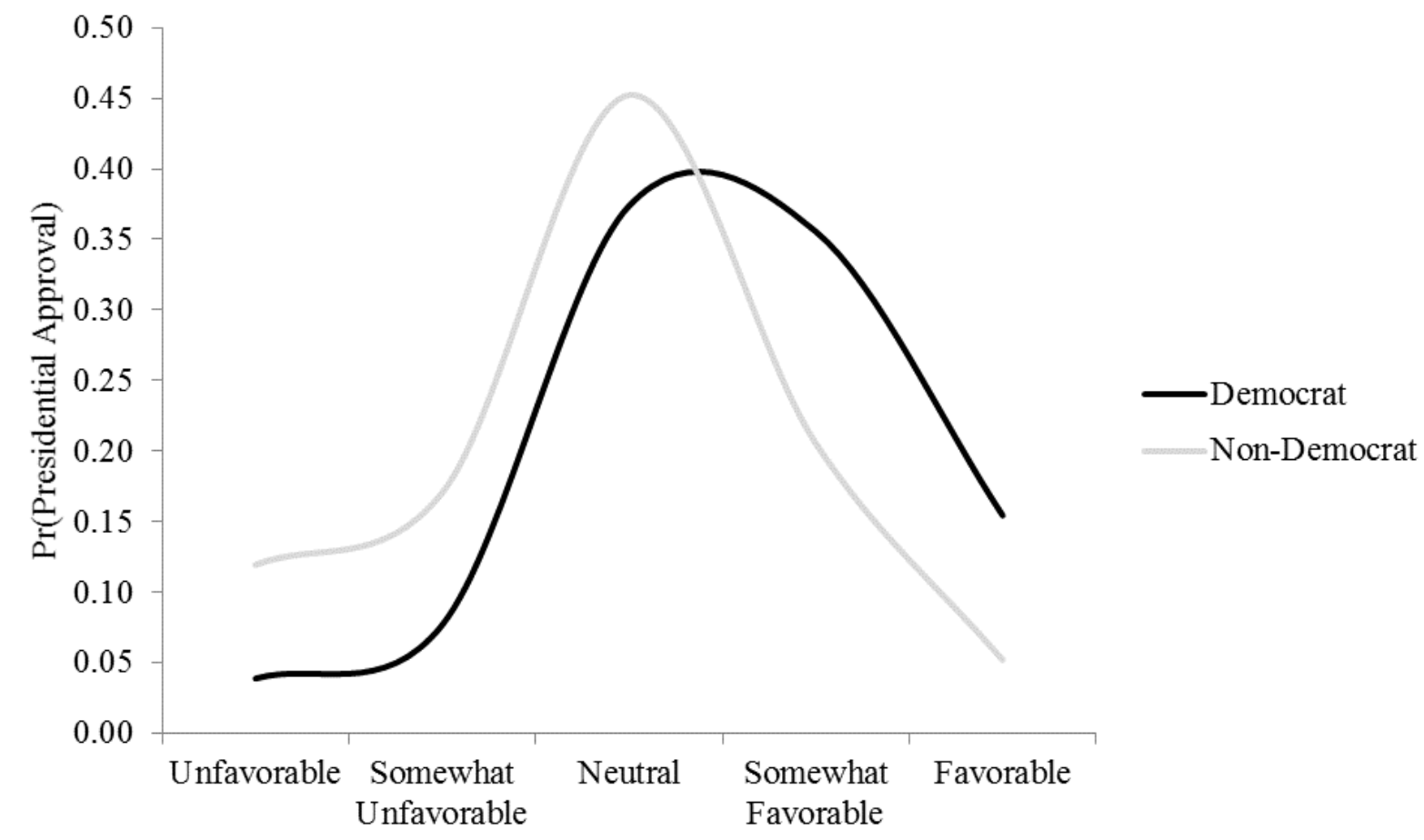

Our next model tests the probability of support for impeachment when respondents are exposed to the presidential scandal that did not involve an illegal action (i.e., policy mistake scandal) in comparison to respondents who were exposed to the control condition. Once again we focus on the interaction term between party and treatment assignment. Table 5 shows the results, which provide support for Expectation 3. The results suggest that when there is a scandal that does not involve an illegal action, partisanship does not have a statistically significant impact on indicating that the President should be impeached. In short, the policy mistake scandal has no effect on the President's partisans - they pass off the information as general political attacks that all presidents face. Such information has no effect on their support for impeaching the President either positively or negatively. Moreover, none of the variables included in the model (i.e., ideology, race, sex and ethnicity) had a statistical significant impact on the outcome 
variable. Again, even among groups we might expect to favor the President (more liberal respondents, Black respondents, female respondents), a scandal has no clear effect on the perception of wrongdoing significant enough to impeach the president among these groups.

TABLE 5: Logit Regression predicting the probability of impeachment for respondents exposed to a political scandal that did not involve an illegal action

\begin{tabular}{|c|c|}
\hline & Coef. \\
\hline \multirow[t]{2}{*}{ Policy Not-Illegal } & -0.08 \\
\hline & $(0.24)$ \\
\hline \multirow[t]{2}{*}{ Democrat } & -0.09 \\
\hline & $(0.32)$ \\
\hline \multirow[t]{2}{*}{ Policy Not-Illegal x Democrat } & -0.44 \\
\hline & $(0.45)$ \\
\hline \multirow[t]{2}{*}{ Ideology } & 0.15 \\
\hline & $(0.13)$ \\
\hline \multirow[t]{2}{*}{ Female } & 0.15 \\
\hline & $(0.20)$ \\
\hline \multirow[t]{2}{*}{ Black } & -0.12 \\
\hline & $(0.40)$ \\
\hline \multirow[t]{2}{*}{ White } & -0.01 \\
\hline & $(0.29)$ \\
\hline \multirow[t]{2}{*}{ Asian } & 0.20 \\
\hline & $(0.33)$ \\
\hline \multirow[t]{2}{*}{ Hispanic } & 0.15 \\
\hline & $(0.25)$ \\
\hline \multirow[t]{2}{*}{ Constant } & $-1.47 * * *$ \\
\hline & $(0.33)$ \\
\hline Observations & 662 \\
\hline PseudoR ${ }^{2}$ & 0.0127 \\
\hline$\chi^{2}$ & 8.180 \\
\hline $\mathrm{p}>\chi^{2}$ & 0.516 \\
\hline
\end{tabular}

Standard errors in parentheses

$* * * \mathrm{p}<0.01, * * \mathrm{p}<0.05, * \mathrm{p}<0.1$ 


\section{Discussion and Conclusion}

In answer to the question raised at the beginning of this article - does partisanship restrict scandal - partisanship helps presidents maintain minimum levels of public support. The results of this paper put in perspective the impacts that political scandals may have among partisans and non-partisans and its consequences. One caveat is the limitation of experimental research in the sense that the effects are temporary and treatment-bound in the sense that we experimentally manipulate illegal presidential activity, which may be less than credible to a respondent given that the events may not capture reality. Despite these limitations inherent in all survey experimental work, the results of this paper find that partisans exposed to the presidential "scandal" that involved an illegal action are less likely to indicate that they would like to see the President impeached and removed from office in comparison to partisans who were exposed to the control condition. Moreover, partisans, even after being exposed to a policy failure involving an illegal action tend to support to the President in comparison with non-partisans. Party identification not only "shields" partisans from political scandals but when exposed to one party identification seems to activate partisans" "psychological attachment" (Campbell et. al. 1960) prompting group identity and loyalty (Huddy 2003) manifested by being the group less likely to hold unfavorable views of the President.

Political cohesion among Democrats is developed through the creation of a subjective identity via party identification, which resembles religious affiliation in the sense of not only belonging to a particular political party but in the sense of absorbing the political doctrine of the party (Green at al. 2002) and manifesting it by being supportive of the quintessential leader of the political party: the President. Partisans not only seem to be oblivious and agreeable in looking the other way for potentially illegal scandalous activity but will go as far as to maintain either a neutral or somewhat positive evaluation of the President. In fact presidential support for impeachment declines significantly amongst co-partisans even in the face of reported illegal activity. Race only played an important role in predicting presidential support, not support for impeachment. A plausible explanation may be given by African Americans' sense of group membership and identification (Tajfel 1981) or what Dawson calls "linked fate," which prompts solidarity between group members and thus sticking with the President.

From an electoral perspective our results suggest that the delicate relationship between politicians and voters is kept somewhat intact and does not appear to be significantly damaged by the shadow casted by a political scandal. Partisanship provides political actors in a scandal with support regardless of the legality of the policy itself. The stability of government and the institutional duration of these elected officials is therefore oddly related to the amount of partisanship generated by these scandals. Despite the obvious problem of having a president involved in illegal activity, partisan patterns provide support for a president accused of serious (and likely impeachable) wrongdoing. An important point for future research is to test how partisans react when facing different types and magnitudes of scandals and different potential perpetrators. Clearly, the type, severity and who is involved in the scandal may have different impacts on how partisans process and react to the scandal.

From a normative perspective these findings are problematic because partisans have serious blinders on when it comes to identifying potential problems in the system. Partisans do not see illegal activity as impeachable despite evidence that the events may warrant such an 
inquiry. The creeping cancer of illegal activity cannot be removed from constitutional governance if there is no consensus on what the effect of illegal activities should be. This partisan limitation complicates the ability of the system to adequately maintain a separation of powers and enforcement of that balance through impeachment. Madison's worst nightmare was an "uncheckable" power accumulating in a single branch of government. Our findings show that the system's integrity is potentially compromised by partisan limitations on support for clear checks and balances. 


\section{Bibliography}

Abramowitz, Alan I., and Kyle L. Saunders. 1998. "Ideological Realignment in the U.S.

Electorate." Journal of Politics 60 (3): 634-52.

Abramowitz, Alan I. 2010. The Disappearing Center: Engaged Citizens, Polarization and American Democracy. New Haven: Yale University Press.

Alterman, Eric. 2004. When Presidents Lie: A History of Official Deception and Its Consequences. New York: Penguin Group.

Barrett, Paul M. 2013. “'Fast and Furious' Scandal Returns to Haunt Obama.” Bloomberg Businessweek, May 21.

Basinger, Scott J. 2013. "Scandals and Congressional Elections in the Post-Watergate Era." Political Research Quarterly.

Baum, Matthew and Samuel Kernell. 1999. "Has Cable Ended the Golden Age of Presidential Television?” American Political Science Review 93, no. 1 (1999): 99-114.

Baufumi, Joseph and Robert Y. Shapiro. 2009. “A New Partisan Voter.” Journal of Politics 71 (1): 1-24.

Beckmann, Matthew N. 2010. Pushing the Agenda: Presidential Leadership in U.S. Lawmaking, 1953-2004. New York: Cambridge University Press.

Bok, Sissela. 1989. Lying: Moral Choice in Public and Private Life. New York: Vintage.

Bond, Jon R., and Richard Fleisher. 1990. The President in the Legislative Arena. Chicago: The University of Chicago Press.

Bowler, Shaun and Jeffrey A. Karp. 2004. 'Politicians, Scandals and Trust in Government." Political Behavior 26 (3): 271-287.

Busby, Robert. 2001. Defending the American Presidency: Clinton and the Lewinsky Scandal. Gordonsville, VA: Palgrage Macmillan.

Carson, Jamie, Michael Crespin, Charles Finocchiaro, and David Rohde. 2007. "Redistricting and Party Polarization in the U.S. House of Representatives." American Politics Research 35 (4): 878-904.

Cohen, Jeffrey E. 2008. The Presidency in the Era of 24-Hour News. Princeton: Princeton University Press. 
Covington, Cary R., J.M. Wrighton and R. Kinney. 1995. "A 'Presidency-Augmented' Model of Presidential Success on House Roll Call Votes." American Journal of Political Science 39 (4): 1001-24.

Chanley, Virginia A., Thomas J. Rudolph and Wendy Rahn. 2000. "The Origins and Consequences of Public Trust in Government. A Time Series Analysis." Public Opinion Quarterly 64 (3): 239-56.

Dancey, Logan. 2012. “The Consequences of Political Cynicism: How Cynicism Shapes Citizens' Reactions to Political Scandals.” Political Behavior 34 (2): 411-23.

Dancey, Logan. 2013. "The Consequences of Political Cynicism: How Cynicism Shapes Citizens' Reactions to Political Scandals." Political Behavior.

Dimock, Michael A. and Gary C. Jacobson. 1995. "Checks and Choices: The House Bank Scandal's Impact on Voters in 1992.” Journal of Politics 57 (4): 1143-59.

Doherty, David, Conor M. Dowling and Michael G. Miller. 2011. "Are Financial or Moral Scandals Worse? It Depends." PS (3): 749-761.

Druckman, James N. and Cindy D. Kam. 2011. "Students as Experimental Participants: A Defense of the Narrow Data Base." In Handbook of Experimental Political Science. Eds. James N. Drickman, Donald P. Green, James H. Kuklinski, and Arthur Lupia. New York: Cambridge University Press, 41-57.

Edwards, III, George C. 1989. At the Margins. New Haven: Yale University Press.

Edwards III, George C. 2003. On Deaf Ears: The Limits of the Bully Pulpit. New Haven, CT: Yale University Press.

Edwards III, George C. 2007. Governing by Campaigning: The Politics of the Bush Presidency. New York: Pearson.

Farnsworth, Stephen J. and S. Robert Lichter. 2006. The Mediated Presidency: Television News and Presidential Governance. Lanham, MD: Rowman \& Littlefield.

Fisher. A. Ronald. 1925. Statistical Methods for Research Workers. Edinburgh: Oliver \& Boyd Fisher, A. Ronald. 1926. The Arrangement of Field Experiments. Journal of the Ministry of Agriculture of Great Britain. 33, 505-513.

Fousek, John, and David Wasserman. 2010. "Ethical Issues in U.S. Presidential Leadership," Presidential Studies Quarterly 40: 1-8. 
Funk, Carolyn L. 1996. "The Impact of Scandal on Candidate Evaluations: An Experimental Test of the Role of Candidate Traits." Political Behavior 18 (1): 1-24.

Galston, William. 2010. "Commentary: Ethics and Character in the U.S. Presidency," Presidential Studies Quarterly 40: 90-101.

Gelman, Andrew. 2009. Red State, Blue State, Rich State, Poor State: Why Americans Vote the Way They Do. Princeton: Princeton University Press.

Ginsberg, Benjamin, and Martin Shefter. 1999. Politics by Other Means: Politicians, Prosecutors and the Press from Watergate to Whitewater. W.W. Norton.

Green, Donald; Bradley Palmquist and Erick Schickler 2002. Partisan Hearts and Minds: Political Parties and the Social Identities of Voters. New Haven: Yale University Press

Hennessey, Kathleen. 2011. "Holder Decries 'Gotcha Games' in Fast and Furious Testimony." Los Angeles Times, November 8.

Hetherington, Marc. J. 1998. "The Political Relevance of Political Trust." American Political Science Review 92 (4): 791-808.

Hetherington, Marc J. 1999. "The Effect of Political Trust on the Presidential Vote, 1968-96." American Political Science Review 93 (2): 311-326.

Hetherington, Marc J. 2003. Why Trust Matters: Declining Political Trust and the Demise of American Liberalism. Princeton: Princeton University Press.

Hetherington, Marc J. and Thomas J. Rudolph. 2008. "Priming, Performance and the Dynamics of Political Trust." Journal of Politics 70 (2): 498-512.

Hinojosa, Victor J. and Anibal S. Perez-Linan. 2006. "Presidential Survival and the Impeachment Process: The United States and Colombia.” Political Science Quarterly 121 (4): 653-675.

Huddy, Leonie. 2003. “Group Identity and Political Cohesion” In Oxford Handbook of Political Psychology. Eds. David O. Sears, Leonie Huddy and Robert Jervis. New York: Oxford University Press, 511-558.

Iyengar, Shanto, Gaurav Sood and Yphatch Lelkes. 2012. "Affect, Not Ideology: A Social Identity Perspective on Polarization.” Public Opinion Quarterly 76(3): 405-31.

Iyengar, Shanto and Sean J. Westwood. 2015. "Fear and Loathing Across Party Lines: New Evidence on Group Polarization.” American Journal of Political Science 59 (3): 690-707. 
Jackson, David. 2012. "Obama Claims Executive Privilege; Holder Held in Contempt.” USA Today, June 20.

Jacobson, Gary. 2011. “The Republican Resurgence in 2010.” Political Science Quarterly 126 (1): $27-52$.

Kernell, Samuel and Laurie L. Rice. 2011. "Cable and the Partisan Polarization of the President's Audience," Presidential Studies Quarterly 41 (4): 693-711.

Keith, Bruce E., David B. Magelby, Candice J. Nelson, Elizabeth Orr, Mark C. Westyle, Raymond E.

Wolfinger. 1992. The Myth of the Independent Voter. Los Angeles: University of California Press.

Kiousis, Spiro. 2003. "Job Approval and Favorability: The Impact of Media Attention to the Lewinsky Scandal on Public Opinion of Bill Clinton," Mass Communication \& Society 6: 435-51

Kriner, Douglas and Liam Schwartz. 2009. "Partisan Dynamics and the Volatility of Presidential Approval." British Journal of Political Science 39 (3): 609-31.

Krosnick, Jon A. and Donald R. Kinder. 1990. "Altering the Foundations of Support for the President through Priming." American Political Science Review 84: 497-512.

Lau, Richard R., and David P. Redlawsk. "Advantages and Disadvantages of Cognitive Heuristics in Political Decision Making." American Journal of Political Science, vol. 45, no. 4, 2001, pp. 951-971

Lawrence, Regina G., W. Lance Bennett, and Valerie Hunt. 1999. “Toward a Fuller Model of Mediated Political Communication: Public Engagement with the Lewinsky Scandal." Paper presented at the annual meeting of the American Political Science Association, Atlanta, GA, September 2-5.

Lawrence, Regina G. and W. Lance Bennett. 2001. "Rethinking Media Politics and Public Opinion: Reactions to the Clinton-Lewinsky Scandal." Political Science Quarterly 116 (3): 425-446.

Levendusky, Matthew. 2009. The Partisan Sort: How Liberal Became Democrats and Conservatives Became Republicans. Chicago: University of Chicago Press.

Marion, Nancy. 2010. The Politics of Disgrace: The Role of Political Scandal in American Politics. Carolina: Carolina Academic Press. 
Markus, Hazel, Jeanne Smith, and Richard L. Moreland. 1985. "Role of the Self-Concept in the Perception of Others." Journal of Personality and Social Psychology 49(6): 1494-1512.

McCarty, Nolan. 2012. "Hate Our Polarized Politics? Why You Can't Blame Gerrymandering." The Washington Post, October 26.

McCarty, Nolan, Keith T. Poole and Howard Rosenthall. 2008. Polarized America: The Dance of Ideology and Unequal Riches. Boston: MIT Press.

McCarty, Nolan, Keith T. Poole and Howard Rosenthall. 2009. "Does Gerrymandering Cause Polarization?" American Journal of Political Science 53 (3): 666-680.

Milkis, Sidney M., Jesse H. Rhodes and Emily J. Charnock. 2012. "What Happened to PostPartisanship? Barack Obama and the New American Party System." Perspectives on Politics 10 (1): 57-76.

Nussbaum, Shiri, Yaacov Trope, and Nira Liberman. 2003. "Creeping Dispositionism: The Temporal Dynamics of Behavior Prediction." Journal of Personality and Social Psychology 84(3): 485-97.

Newman, Brian and Andrew Forcehimes. 2010. "' Rally Round the Flag' Events for Presidential Approval Research." Electoral Studies 29 (1): 144-54.

Newman, Brian and Emerson Siegle. 2010. "The Polarized Presidency: Depth and Breadth of Public Partisanship." Presidential Studies Quarterly 40 (2): 342-363.

Ostrom, Jr. Charles W. and Simon, Dennis M. 1988. "The Man in the Teflon Suit? The Environmental Political Drama and Popular Support in the Reagan Presidency." Public Opinion Quarterly 53 (3): 58-82.

Perry, Tony. 2012. “'Fast and Furious' Defendant Gets Prison for Buying Guns.” Los Angeles Times, October 15.

Pew Research Center. 2012. Trends in American Values: 1987-2012. Washington, DC: The Pew Research Center for the People and the Press.

Peterson, Mark A. 1990. Legislating Together: The White House and Capitol Hill from Eisenhower to Reagan. Cambridge, Mass.: Harvard University Press.

Petersen, Michael.B, Skov, Martin, Serritzlew, Soren and Ramsoy, Thomas. "Motivated Reasoning and Political Parties: Evidence for Increased Processing in the Face of Party Cues" Political Behavior (2013) 35: 831. 
Ponder, Daniel and C. David Moon. 2005. "A Tale of Three Variables: Exploring the Impact of Alternative Measures of Presidential Approval on Congressional Voting." Congress \& the Presidency 23 (Autumn): 157-69.

Pfiffner, James P. 2004. The Character Factor: How We Judge America's Presidents. College Station: Texas A\&M University Press.

Praino, Rodrigo, Daniel Stockemer and Vincent G. Moscardelli. 2013. "The Lingering Effect of Scandals in Congressional Elections: Incumbents, Challengers, and Voters." Social Science Quarterly 94 (4): 1045-61.

Puglisi, Riccardo and James M. Snyder, Jr. 2011. "Newspaper Coverage of Political Scandals." Journal of Politics 73 (30: 931-950.

Renshon, Stanley A. 2002. "The Polls: The Public's Response to the Clinton Scandals, Part 1: Inconsistent Theories, Contradictory Evidence.” Presidential Studies Quarterly 32 (1): 169-184.

Rohde, David W. and Meredith Barthelemy. 2010. "The President and Congressional Parties in an Era of Polarization." In the Oxford Handbook and the American Presidency, eds. George C. Edwards III and William G. Howell. New York: Oxford University Press.

Rottinghaus, Brandon. 2013. "Surviving Scandal: The Institutional and Political Dynamics of National and State Executive Scandals." PS: Political Science and Politics 47 (1): 131-140.

Schneider, Bill. 2003. “Illinois Governor Leaves a Legacy.” CNN.com, January 20.

Sinclair, Barbara. 2006. Party Wars: Polarization and the Politics of National Policy Making. Norman: University of Oklahoma Press.

Shadish, R. William; Cook, D. Thomas; Campbell, T. Donald. 2002. "Experimental and QuasiExperimental Designs for Generalized Causal Inference”. Boston: Houghton Mifflin Company.

Shah, Dhavan V. and Mark D. Watts, David Domke and David P. Fan. 2002. "News Framing and Cueing of Issue Regimes." Public Opinion Quarterly 66 (3): 339-370.

Sonner, Molly W. and Clyde Wilcox. 1999. "Forgiving and Forgetting: Public Support for Bill Clinton During the Lewinsky Scandal." PS XXXII (3): 554-557.

Taber, Charles S., and Milton Lodge. "Motivated Skepticism in the Evaluation of Political Beliefs.” American Journal of Political Science, vol. 50, no. 3, 2006, pp. 755-769.

Tajfel, Henri. 1981. Human Groups and Social Categories. Cambridge: Cambridge University Press. 
Tedin, Kent, Brandon Rottinghaus and Harrell Rodgers. 2010. "When the President Goes Public: The Consequences of Communication Mode for Opinion Change Across Issue Types and Groups," Political Research Quarterly (64): 506-19.

Theriault, Sean M. 2008. Party Polarization in Congress. New York: Cambridge University Press.

Theriault, Sean M. and David Rhode 2011. "The Gingrich Senators and Party Polarization in the U.S. Senate.” Journal of Politics 73 (4): 1011-1024.

Thompson, John B. 2000. Political Scandal: Power and Visibility in the Media Age. New York: Wiley.

Vonnahme, Beth Miller. 2014. "Surviving Scandal: An Exploration of the Immediate and Lasting Effects of Scandal on Candidate Evaluation." Social Science Quarterly. Fothcoming.

Weisman, Jonathan and Charlie Savage. 2012. "House Finds Holder in Contempt Over Inquiry on Guns." The New York Times, June 28.

Welch, Reed L. 2003. "Presidential Success in Communicating with the Public Through Televised Addresses." Presidential Studies Quarterly (33): 347-65.

Welsh, Susan and John R. Hibbing. 1997. "The Effect of Charges of Corruption on Voting Behavior in Congressional Elections, 1982-1990." Journal of Politics 59 (1): 226-239.

Woessner, Matthew C. 2005. "Scandal, Elites and Presidential Popularity: Considering the Importance of Cues in Public Support of the President." Presidential Studies Quarterly 35: 94-115.

Young, Garry and William B. Perkins. 2005. "Presidential Rhetoric, the Public Agenda, and the End of Presidential Television's 'Golden Age.’” Journal of Politics (67): 1190-205.

Zaller, John R. 1999. “Monica Lewinsky’s Contribution to Political Science.” PS: Political Science 31 (2): 182-9. 
Appendix

TABLE A1. t-test

\begin{tabular}{|c|c|c|c|c|c|c|c|}
\hline \multirow{3}{*}{$\begin{array}{l}\text { Policy } \\
\text { Illegal }\end{array}$} & \multirow{2}{*}{$\begin{array}{l}\quad \text { Group } \\
\text { Non- } \\
\text { Democrats }\end{array}$} & \multirow{2}{*}{$\begin{array}{l}\text { Obs } \\
214\end{array}$} & \multirow{2}{*}{$\begin{array}{l}\text { Mean } \\
0.30\end{array}$} & \multirow{2}{*}{$\begin{array}{c}\text { Std. Err. } \\
0.03\end{array}$} & \multirow{2}{*}{$\begin{array}{l}\text { Std. } \\
\text { Dev. }\end{array}$} & \multicolumn{2}{|c|}{$95 \%$ Conf.Interval } \\
\hline & & & & & & 0.24 & 0.36 \\
\hline & Democrats & 124 & 0.11 & 0.03 & 0.32 & 0.06 & 0.17 \\
\hline & Difference & & 0.19 & 0.05 & & 0.09 & 0.28 \\
\hline
\end{tabular}

TABLE A2. Predicted Margins Corresponding to Table 3

\begin{tabular}{lcccccc} 
& Margin & Std. Err. & $\mathrm{z}$ & \multicolumn{2}{c}{$\mathrm{P}>\mathrm{z}$} & \multicolumn{2}{c}{$95 \%$ Conf.Interval } \\
\hline Control Condition & 0.20 & 0.02 & 9.20 & 0.00 & 0.16 & 0.25 \\
President-Illegal Condition & 0.23 & 0.02 & 10.19 & 0.00 & 0.19 & 0.27 \\
Non-Democrat & 0.25 & 0.02 & 11.58 & 0.00 & 0.20 & 0.29 \\
Democrat & 0.16 & 0.03 & 5.90 & 0.00 & 0.10 & 0.21 \\
Control x Non-Democrat & 0.21 & 0.03 & 7.51 & 0.00 & 0.15 & 0.26 \\
Control x Democrat & 0.20 & 0.04 & 4.86 & 0.00 & 0.12 & 0.29 \\
President-Illegal x Non- & & & & & & 0.22 \\
Democrat & 0.29 & 0.03 & 9.12 & 0.00 & 0.35 \\
President-Illegal x Democrat & 0.11 & 0.03 & 3.63 & 0.00 & 0.05 & 0.17 \\
\hline
\end{tabular}


TABLE A3. Predicted Margins Corresponding to Table 4 Policy Illegal Treatment

\begin{tabular}{lcccccc} 
& Margin & Std. Err. & $\mathrm{z}$ & $\mathrm{P}>\mathrm{z}$ & \multicolumn{2}{c}{$95 \%$ Conf.Interval } \\
\hline Unfavorable-Non-Democrat & 0.12 & 0.02 & 6.41 & 0.00 & 0.08 & 0.16 \\
Unfavorable-Democrat & 0.04 & 0.01 & 3.76 & 0.00 & 0.02 & 0.06 \\
Somewhat Unfavorable-Non- & & & & & & \\
Democrat & 0.17 & 0.02 & 7.48 & 0.00 & 0.13 & 0.22 \\
Somewhat Unfavorable-Democrat & 0.08 & 0.02 & 4.79 & 0.00 & 0.05 & 0.11 \\
Neutral-Non-Democrat & 0.45 & 0.03 & 15.31 & 0.00 & 0.39 & 0.51 \\
Neutral-Democrat & 0.37 & 0.03 & 12.64 & 0.00 & 0.32 & 0.43 \\
Somewhat Favorable-Non- & & & & & & 0.16 \\
Democrat & 0.21 & 0.02 & 8.91 & 0.00 & 0.16 & 0.25 \\
Somewhat Favorable-Democrat & 0.36 & 0.04 & 10.00 & 0.00 & 0.29 & 0.43 \\
Favorable-Non-Democrat & 0.05 & 0.01 & 4.41 & 0.00 & 0.03 & 0.08 \\
Favorable-Democrat & 0.15 & 0.03 & 6.01 & 0.00 & 0.10 & 0.20 \\
\hline
\end{tabular}

TABLE A4. Predicted Margins Corresponding to Table 4 Control Treatment

\begin{tabular}{lcccccc} 
& Margin & Std. Err. & $z$ & P z & \multicolumn{2}{c}{$95 \%$ Conf.Interval } \\
\hline Unfavorable-Non-Democrat & 0.16 & 0.02 & 7.47 & 0.00 & 0.12 & 0.20 \\
Unfavorable-Democrat & 0.05 & 0.01 & 3.67 & 0.00 & 0.02 & 0.07 \\
$\begin{array}{l}\text { Somewhat Unfavorable-Non- } \\
\text { Democrat }\end{array}$ & 0.17 & 0.02 & 7.31 & 0.00 & 0.12 & 0.21 \\
Somewhat Unfavorable-Democrat & 0.07 & 0.02 & 4.36 & 0.00 & 0.04 & 0.11 \\
Neutral-Non-Democrat & 0.43 & 0.03 & 14.33 & 0.00 & 0.37 & 0.49 \\
Neutral-Democrat & 0.35 & 0.03 & 11.33 & 0.00 & 0.29 & 0.41 \\
Somewhat Favorable-Non- & & & & & & 0.15 \\
Democrat & 0.20 & 0.02 & 8.46 & 0.00 & 0.15 \\
Somewhat Favorable-Democrat & 0.36 & 0.04 & 9.28 & 0.00 & 0.29 & 0.44 \\
Favorable-Non-Democrat & 0.05 & 0.01 & 4.18 & 0.00 & 0.03 & 0.07 \\
Favorable-Democrat & 0.16 & 0.03 & 5.73 & 0.00 & 0.11 & 0.22 \\
\hline
\end{tabular}

